\title{
Paraprofessional Catalogers in ARL Libraries
}

\section{Sever Bordeianu and Virginia Seiser}

\begin{abstract}
The authors conducted a survey of ARL member libraries to identify the minimum education and experience required of paraprofessional catalogers. The majority of surveyed libraries responded that they use paraprofessionals to catalog various types of materials. A higher number of libraries use paraprofessionals in copy cataloging than in original cataloging. Although no single model of education and training for paraprofessional catalogers exists, certain patterns emerge. The educational expectations for copy catalogers are lower than those for original catalogers. Training takes place on the job. The library profession is not as far along in developing structured paraprofessional degree requirements along the same lines as other professions, such as law or medicine.
\end{abstract}

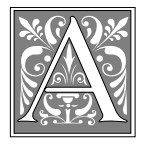

t the beginning of this century, graduates of the newly created library schools were being hired to fill positions formerly held by staff members who had acquired their knowledge of library work on the job. The appearance of librarians with professional degrees diminished the opportunities for nondegreed staff to work their way up within the system. As we approach the end of the century, the pendulum appears to be swinging the other way. A number of academic libraries are hiring paraprofessionals to do some jobs that were formerly restricted to librarians with the MLS degree. However, this is not uniformly the case. Nor is there general agreement about important issues such as hiring prerequisites, on-the-job training, and promotion criteria among those libraries that are hiring paraprofessionals to fill higher-level positions.
The University of New Mexico General Library has a number of successful examples of staff members with little postsecondary education, but high aptitude, and many years of library experience, who have taken advantage of opportunities for on-the-job training to work their way up to higher-level paraprofessional positions. Recently however, the University of New Mexico Human Resources Department implemented a new staff job classification system for the entire campus, including the libraries.

From the library perspective, two of the more controversial features of the new staff classification system were the significantly more stringent education requirements for higher-level paraprofessional positions and the absence of a provision to allow experience to be substituted for years of education in meeting minimum requirements. Some library staff members

Sever Bordeianu is Head of the Serials Cataloging Section at the University of New Mexico; e-mail: sbordeia@unm.edu. Virginia Seiser is Director, Budget and Personnel, at the University of New Mexico; e-mail:vseiser@unm.edu. 
who had worked their way up to higherlevel positions under the old system now found themselves "grandfathered in" to positions they could not have qualified for under the new system. For some, personal circumstances made it unfeasible to take more than one college course per semester. At that rate, such staff members would qualify for retirement before they could meet the degree requirements even to qualify for a transfer to another position in their current grade, much less for a promotion to the next higher grade. This had a significant negative effect on the morale of some of the library's outstanding staff members. The university had created a "sheepskin ceiling."

When the university established a committee to make recommendations about career ladders within the library "job family," the opportunity was taken to address the issue of education requirements for specific library positions. To provide more context for the discussion, information was gathered from comparable libraries elsewhere in the country.

\section{Literature Review}

Discussions about the role of paraprofessionals in libraries abound in the library literature. This is not surprising, given the estimate that paraprofessionals constitute between 50 and 85 percent of the library workforce. ${ }^{1}$ Jennifer A. Younger has asserted that support staff have assumed increasingly responsible assignments in libraries, and by the mid-1990s, the balance in libraries is shifting toward more support staff and fewer librarians. ${ }^{2}$ These statements pertain to all areas of librarianship, in both public and technical services. This article focuses on the role of paraprofessionals in cataloging. The term paraprofessional is used here to mean a library employee who does not have master's degree in library/information science.

The participation of paraprofessionals in cataloging activities is amply documented in the library literature. Several studies performed during the past two decades have indicated that paraprofes- sional participation in cataloging has been increasing steadily since $1977 .{ }^{3}$ Two surveys of ARL libraries confirm these findings. In 1986, Sharon E. Clark found that of fifteen respondents to a survey sent to nineteen ARL member libraries, most reported that staff performed copy cataloging. ${ }^{4}$ In 1997, Deborah A. Mohr and Anita Schunemann reported that 77 percent of ARL respondents to a 1995 survey indicated that paraprofessionals were involved in some form of original cataloging. ${ }^{5}$ Most other articles on this topic have reported similar findings and agree with Daren Callahan and Judy MacLeod's assertion that "responsibility for much of the copy cataloging and even some simple original cataloging is increasingly given to paraprofessionals." 6

Although the trend toward increased participation of paraprofessionals in cataloging is recognized in the literature, there is also agreement that these catalogers need to be trained. Opinions differ about the level of cataloging appropriate to assign to paraprofessionals, ranging from simple copy cataloging to complex original cataloging. The literature provides little detailed information on the educational background or number of years of relevant experience necessary for a paraprofessional to perform specific cataloging assignments.

In a study of job descriptions for paraprofessional catalogers for the years 1975, 1981, and 1990, Carol P. Johnson found that during this period, paraprofessional jobs were not significantly upgraded due to automation. However, she stated that due to this changing environment, the analysis of qualifications needed to perform at each level of the library organization is "a legitimate subject of research."7

Sheila S. Intner, a prominent library educator, asserted that the education of copy catalogers is different from that of professionals and envisions an educational system for paraprofessional catalogers similar to that for paraprofessionals in the fields of law and medicine, without giving specifics as to what should be taught in these programs. ${ }^{8}$ Claire-Lise 
Benaud mentioned a bachelor's degree and an unspecified number of years of experience as a minimum requirement for paraprofessional catalogers. ${ }^{9}$ Callahan and McLeod concluded that because required skills for paraprofessional catalogers have changed from typing and filing skills to experience with computer applications and an understanding of library organization, paraprofessionals need a comprehensive education that encourages critical thinking. ${ }^{10}$

Two articles have addressed specific requirements for either education or training. Robert M. Hiatt described in detail the education and training required of paraprofessional catalogers at the Library of Congress in $1987 .{ }^{11}$ At that time, catalogers at the library specialized in either descriptive or subject cataloging. The system had an elaborate formula for providing an equivalent to the MLS through substitution of a BA and three years of general or two years of specialized library experience for descriptive catalogers. In the case of subject catalogers, a subject master's degree could be substituted for the BA and/or MLS. In both cases, expertise in at least two foreign languages also was required. James S. Chervinko provided a five-step model to be used in the training of paraprofessional catalogers. ${ }^{12}$ The model assumes certain prerequisites, such as the trainee's familiarity with the MARC record and AACR2, broad subject competence, knowledge of a foreign language, the capacity to recognize problems and the willingness to ask questions, as well as compatibility between trainer and trainee. The five steps consist of learning and mastering increasingly complex cataloging tasks, starting with simple adaptive cataloging and ending with less-thancomplex original cataloging. These two reports provide useful information on some of the educational and training requirements for paraprofessional catalogers.

The most comprehensive study on the role of paraprofessionals in libraries was conducted by Larry R. Oberg, Mark E. Mentges, P. N. McDermott, and Vitoon
Harusadangkul in 1992. From a sample of nearly 500 libraries, consisting of ARL libraries and Carnegie Classification universities, the authors received 390 usable responses. The study was broad and looked at all aspects of paraprofessional involvement in libraries. For cataloging, the findings indicated that over 90 percent of ARL libraries assign copy cataloging to paraprofessionals, 51 percent assign original description, and 36 percent assign original description, subject analysis, and classification. The numbers are slightly lower for the study's non-ARL sample. ${ }^{13}$ Regarding education, the study found 93 percent of ARL respondents required a high school degree of all or some of their employees, 58 percent an associate degree, 76 percent a bachelor's degree, and 24 percent a graduate degree. Of the Carnegie sample libraries, the study reported that 98 percent required a high school degree, 62 percent an associate degree, 64 percent a bachelor's degree, and 9 percent a graduate degree. ${ }^{14}$ Ninetyseven percent of ARL libraries and 65 percent of Carnegie libraries reported that they employ at least some paraprofessionals who hold a degree higher than what is required. This finding seems to indicate that educational requirements for paraprofessionals in research libraries does not present a problem in the area of employee recruitment, as candidates often exceed the minimum required education level.

Another landmark study was conducted by Patricia A. Eskoz over a fouryear period. Eskoz sent a survey to the cataloging departments of 106 libraries in 1983-1984 and followed up with forty of the original respondents via phone interviews in 1986-1987. ${ }^{15}$ Although the purpose of the study was to determine the organizational structures of cataloging departments and to analyze their evolution over the time period under scrutiny, the study did reveal the increased involvement of paraprofessionals in cataloging activities. The article did not address the issue of qualification or training but did state that "cataloging is not a 
mystical art and most of the skills required can be learned on the job."16 This observation, though not empirical, is significant because it expresses unequivocally the attitude of many professionals toward the learning and acquisition of cataloging skills.

The decision was made to focus on paraprofessional cataloging positions because the tasks performed in cataloging are more standardized across libraries than seems to be the case for other types of library positions.

The literature indicates that most libraries have in-house training programs for paraprofessional catalogers. Jane B. Robbins stated that the teaching of cataloging is taking place in libraries rather than library schools. ${ }^{17}$ Clark's 1987 survey of nineteen ARL libraries found that slightly more than half the responding libraries operated a formal training program. ${ }^{18}$ Judith Hudson reported that these programs vary from structured classes to individualized one-on-one training. ${ }^{19}$ There is also some indication that the training of paraprofessionals is similar to that of entry-level professional catalogers. ${ }^{20,21}$ Several authors mentioned that whatever the format of the training programs, they are unnecessarily time-consuming. . $^{2,23}$

Finally, there is agreement in the literature that the status of paraprofessional catalogers is an issue. Despite the fact that paraprofessionals are increasingly responsible for the creation of cataloging records in libraries, their salaries and perquisites lag behind those of professional catalogers. Several authors expressed opinions on how to address these inequities. Johnson stated that improvement in the status of paraprofessionals depends on the level of authority, autonomy, and skill assigned to a job. ${ }^{24}$ Chervinko asserted that after paraprofessionals have reached the highest level of competency, presumably similar to that of professional catalogers, they should be given the same rewards and rights as the professionals: job classification upgrades, travel support, time off to study foreign languages, and the proper computer equipment. ${ }^{25}$

\section{Methodology}

ARL has 121 members representing the major research institutions in the United States and Canada. The membership includes 110 academic libraries, among them, the University of New Mexico. ARL maintains an electronic list service linking the library directors for its academic library members by e-mail. In August 1998, the UNM General Library submitted a brief questionnaire by electronic mail to that list.

The decision was made to focus on paraprofessional cataloging positions because the tasks performed in cataloging are more standardized across libraries than seems to be the case for other types of library positions. The questionnaire was designed to be short and simple to encourage quick response. The questions concerned minimum education and experience requirements for paraprofessional cataloging positions at two levels: copy cataloging and original cataloging.

The results of the initial survey were sufficiently interesting to encourage the authors to send out a second request for information to those ARL academic libraries that had not initially responded. This was done in February 1999. The same questions were asked and the same explanatory paragraph used, but this time the query was sent to the library administrator who appeared to have responsibility for the library's overall cataloging effort. Usually, that individual was the head of the catalog department. All but four of the queries were sent electronically to the personal e-mail address of the administrator; the remaining four were sent by U.S. mail when a personal e-mail address could not be readily identified.

\section{Results}

Thirty-one ARL academic library directors provided responses to the August 1998 query, and an additional twentyseven libraries responded to the Febru- 


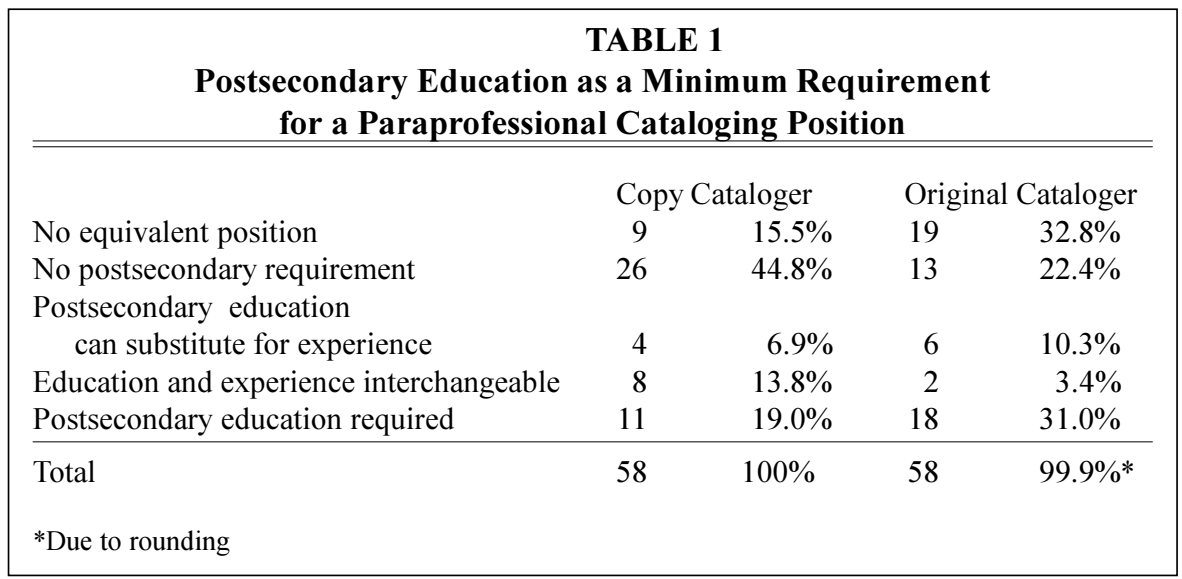

ary 1999 query, for a total of fifty-eight responses. The combined response rate was 52.7 percent.

The questionnaire responses were divided into five categories:

1. No equivalent position (paraprofessionals do not perform the cataloging tasks described in the questionnaire).

2. No postsecondary requirement (education beyond high school is not a prerequisite for hiring paraprofessionals at this level).

3. Postsecondary education required (education beyond high school is a prerequisite for hiring paraprofessionals at this level).

4. Postsecondary education can be substituted for experience (education beyond high school is not an absolute prerequisite but can be counted in lieu of some the years of work experience required for hiring paraprofessionals at this level).

5. Education and experience interchangeable (prerequisites for hiring paraprofessionals at this level can be met by a specified number of years of postsecondary education or work experience or a combination of both).

The number of responses in each of these five categories are shown in table 1.

\section{Paraprofessional COPY Cataloging Positions}

Following are the results for questions about paraprofessional copy cataloging positions:
1. No equivalent position: Nine libraries $(15.5 \%)$ reported that they did not have copy cataloger positions for paraprofessional staff.

2. No postsecondary requirement: Twenty-six libraries (44.8\%) did not count postsecondary education toward the minimum requirements for paraprofessional positions for copy catalogers. Of these twenty-six, three required no experience and three required a passing grade on an examination. The work experience for the remaining libraries ranged from one to six years: Three libraries required one year of experience; seven required two years; one required three years; three required four years; and one required six years. Five libraries required experience but did not specify the number of years required. These results are summarized in table 2.

3. Postsecondaryeducation required:Eleven libraries (19\%) required postsecondary education for paraprofessional copy cataloger positions. The number of years of postsecondary education required ranged from two to four: Four libraries required two years of postsecondary education; one required a three-year diploma (Canadian); and six required four years of college and/or a bachelor's degree. Of the eleven libraries, ten required experience in addition to education. For those libraries that had a specific requirement for years of work experience, the range was from one to five years: Five libraries required 


\begin{tabular}{|c|c|c|}
\hline \multicolumn{3}{|c|}{$\begin{array}{c}\text { TABLE } 2 \\
\text { Experience Required When Postsecondary } \\
\text { Education Does Not Count Toward Meeting } \\
\text { Minimum Requirements } \\
\end{array}$} \\
\hline & $\begin{array}{c}\text { Copy } \\
\text { Cataloger }\end{array}$ & $\begin{array}{l}\text { Original } \\
\text { Cataloger }\end{array}$ \\
\hline No experience required & 3 & 0 \\
\hline Exam required & 3 & 2 \\
\hline "Some" experience required & 5 & 2 \\
\hline 1 year of experience required & 3 & 0 \\
\hline 2 years of experience required & 7 & 6 \\
\hline 3 years of experience required & 1 & 1 \\
\hline 4 years of experience required & 3 & 1 \\
\hline 5 years of experience required & 0 & 2 \\
\hline 6 years of experience required & 1 & 2 \\
\hline Total & 26 & 16 \\
\hline
\end{tabular}

5. Education and experience interchangeable: Eight libraries (13.8\%) had requirements that allowed years of experience and postsecondary education to be counted interchangeably, using variations on a one-toone or two-to-one formula. The sum of years required varied from two to five years.

\section{Paraprofessional Original Cataloging Positions}

Following are the results for the questions one year of work experience in addition to a specified number of years of postsecondary education; one library required two years of work experience; one required three years; and one, five years. Two libraries required work experience in addition to a bachelor's degree but did not specify the number of years. These results are shown in table 3.

4. Postsecondary education can be substituted for experience: Four libraries (6.9\%) required work experience but allowed years of postsecondary education to be substituted for part of the experience. The formulas used varied, but all specified at least one year of experience with some level of postsecondary education or four to five years of experience without additional education. about paraprofessional original cataloging positions:

1. No equivalent position: Nineteen libraries (32.8\%) reported that they did not have original cataloger positions for paraprofessional staff.

2. No postsecondary requirement: Thirteen libraries $(22.4 \%)$ did not count postsecondary education toward the minimum requirements for paraprofessional positions for original catalogers. All thirteen required either a passing grade on an examination or years of work experience. Two libraries required a passing grade on an examination. The work experience requirement for the remaining libraries ranged from two to six years: Three libraries required two years of experience; one required three years; one

\section{TABLE 3}

Combined Minimum Requirements for Those Paraprofessional Copy Cataloging Positions Requiring Postsecondary Education

\begin{tabular}{|c|c|c|c|c|c|c|c|}
\hline $\begin{array}{l}\text { Years of } \\
\text { experience }\end{array}$ & 0 & "Some" & 1 & 2 & 3 & 4 & 5 \\
\hline 2 years of college & & & 3 & & 1 & & \\
\hline 3-year degree* & & & 1 & & & & \\
\hline 4 years of college & 1 & 2 & & & & & 1 \\
\hline Bachelor's degree & & 2 & 1 & 1 & & & \\
\hline
\end{tabular}


TABLE 4

Combined Minimum Requirements for Those Paraprofessional Original
Cataloging Positions Requiring Post-Secondary Education.

\begin{tabular}{|c|c|c|c|c|c|c|c|}
\hline $\begin{array}{l}\text { Years } \\
\text { of experience }\end{array}$ & 0 & "Some" & 1 & 2 & 3 & 4 & 5 \\
\hline 2 years of college & & & 1 & & & & \\
\hline 3 -year degree* & & & & & 2 & & \\
\hline 4 years of college & & & 1 & 2 & & & \\
\hline Bachelor's degree & 1 & 3 & 2 & 4 & 2 & & \\
\hline
\end{tabular}

required four years; two required five years; and two required six years. Two libraries required work experience but did not specify the number of years. The results are summarized in table 2 .

3. Postsecondary education required: Eighteen libraries (31\%) required postsecondary education for paraprofessional positions for original catalogers. The number of years of postsecondary education required ranged from two to four: One library required two years of postsecondary education; two required a three-year diploma (Canadian); and fifteen required four years of college and/ or a bachelor's degree. All but one of the eighteen libraries required work experience. For those libraries that had a specific requirement for years of work experience, the range was from one to three years: Four libraries required one year of experience; six required two years; and four required three years. Three libraries required work experience in addition to a bachelor's degree but did not specify a number of years of experience. These results are shown in table 4 .

4. Postsecondary education can be substituted for experience: Six libraries (10.3\%) required experience but allowed years of postsecondary education to be substituted for part of the experience. The formulas used were quite varied.

5. Education and experience interchangeable: Two libraries (3.4\%) had requirements that allowed years of experience and postsecondary education to be counted interchangeably, on a one-to-one basis. The sum of years required was four in one case and five in the other.

\section{Comments}

A number of responding libraries qualified their responses concerning minimum requirements by indicating that additional education and/or experience was preferred and that most or all of the incumbents in the positions had more than the minimum. The brief questionnaire did not ask specifically about the existence of an examination, so it is possible that more libraries in the sample required an exam than were reported here. Several libraries noted that although they had a system on paper specifying the minimum requirements that outside applicants needed to be considered for positions at that level, the fact was that all the existing positions had been filled by promotion from within the library.

A number of libraries qualified their responses regarding minimum requirements for experience with terms such as relevant or cataloging or library experience. In the case of original cataloging positions, a few libraries specified that candidates had to have experience in the next lower grade; paraprofessionals in those libraries were expected to "work their way up" from copy cataloging to original cataloging within the employing library.

Some libraries volunteered information about specific skill requirements, such as computer skills or foreign-language ability, in addition to years of experience and 
education. Of the libraries requiring postsecondary education, a few were specific about the type of academic program or courses taken. Some required a two-year associate degree (U.S.) or a three-year technical program diploma (Canada); others specified course work in cataloging.

\section{Discussion}

As shown in table 1, most of the responding libraries reported that they employed paraprofessionals to do cataloging. However, fewer libraries reported using paraprofessionals to do original cataloging than copy cataloging.

\section{A higher number of libraries use paraprofessionals in copy cataloging ( $84.5 \%$ of respondents) than in original cataloging $(67 \%$ of respon- dents).}

The majority of libraries that did employ paraprofessional copy catalogers did not require postsecondary education to meet the minimum qualifications for the position. However, many indicated that additional education was desirable and some implied that it was highly unlikely that anyone without additional education would be a successful candidate, given the competition for the job. Most required some experience to meet the minimum qualifications regardless of level of education, and some were very specific about the type of experience required. The libraries indicating that an examination was required implied that this was a measure of work experience, in lieu of specifying a specific number of years of experience.

The responses from the libraries employing paraprofessional original catalogers were less clear-cut regarding postsecondary education as a minimum requirement (see table 1). Excluding the gray area of libraries using formulas for comparability of education and experience, a few more libraries reported a minimum requirement for postsecondary education than those who reported no minimum requirement. Of those reporting no minimum postsecondary education re- quirement, many volunteered the information that it was preferred. Only one library did not require either some experience or a passing grade on a qualifying examination for a paraprofessional position doing original cataloging, and that one was a case requiring a bachelor's degree. Of those reporting a minimum requirement for postsecondary education, the largest cluster of responses was for four years of college and/or a bachelor's degree, as well as two years of experience (see table 4).

\section{Conclusion}

The findings of the current study agree with other reports from the literature. The majority of surveyed libraries responded that they use paraprofessionals to cata$\log$ various types of materials. A higher number of libraries use paraprofessionals in copy cataloging (84.5\% of respondents) than in original cataloging $(67 \%$ of respondents). Although no singular model of education and training for paraprofessional catalogers exists, certain patterns become apparent when analyzing the data from responding libraries.

As would be expected, the educational requirements for copy catalogers are lower than they are for original catalogers. Only 19 percent of respondents required a postsecondary degree for copy catalogers. For the rest of the respondents, the requirements ranged from no postsecondary education to a combination of either some education or some years of experience. Postsecondary education for original paraprofessional catalogers was required by 31 percent of respondents. The rest of the libraries required a variety of other qualifications, ranging from a passing grade on an examination to multiple years of experience. In some cases, experience or postsecondary education can be used interchangeably, but libraries use different formulas for calculating their equivalence. Comments provided by respondents to the questionnaire corroborate another finding from the literature. In many cases, applicants or incumbents in library paraprofessional positions exceed the minimum requirements for that position. 
The picture that emerges from this study is that although the educational requirements for paraprofessional catalogers are not codified to the same extent as for professional catalogers, there is some similarity among libraries in their expectations for these staff. Informal comments provided by respondents, findings from the literature, and direct observation also suggest that the higher-level paraprofessional catalogers usually reach their position by promotion from within, presumably after learning the necessary skills and advancing to the next stage of cataloging complexity.
The library profession is not as far along in developing structured paraprofessional degree requirements as other professions are (such as law or medicine), even though the literature discusses this possibility. ${ }^{26}$ The Canadian system and the U.S. system appear to be developing different standards (e.g., the three-year technical diploma versus the two-year associate degree). The fact that a relatively low number of libraries require postsecondary degrees implies that the workplace is still the preferred place to learn cataloging.

\section{Notes}

1. Terry Rodgers, The Library Professional: Notes from the Underground (Jefferson, N.C.: McFarland, 1997), 1.

2. Jennifer A. Younger, "Support Staff and Librarians in Cataloging," Cataloging \& Classification Quarterly 23, no.1 (1996): 29.

3. Deborah A. Mohr and Anita Schunemann, "Changing Roles: Original Cataloging by Paraprofessionals in ARL Libraries," Library Resources \& Technical Services 41 (July 1997): 206.

4. Sharon E. Clark, "Managing Copy Cataloging in ARL Libraries," SPEC Flyer 136 (JulyAug. 1987): 1.

5. Mohr and Schunemann, "Changing Roles," 216.

6. Daren Callahan and Judy MacLeod, "Management Issues and the Challenge for Cataloging Education," Technical Services Quarterly 13, no. 2 (1996): 16.

7. Carol P. Johnson, "The Changing Nature of Jobs: A Paraprofessional Time Series," College $\mathcal{E}$ Research Libraries 57 (Jan. 1996): 66.

8. Sheila S. Intner, "The Education of Copy Catalogers," Technicalities 11 (Mar. 1991): 4.

9. Claire-Lise Benaud, "The Academic Paraprofessional Cataloger: Underappreciated," Cataloging \& Classification Quarterly 15, no. 3 (1992): 86.

10. Callahan and MacLeod, "Management Issues and the Challenge for Cataloging Education," 17.

11. Robert M. Hiatt, "Education and Training of Cataloging Staff at the Library of Congress," Cataloging \& Classification Quarterly 7, no. 4 (1987): 123.

12. James S. Chervinko, "The Changing State of Original Cataloging: Who's Going to Do It Now?" Illinois Libraries 74 (Dec. 1992): 494.

13. Larry R. Oberg, Mark E. Mentges, P. N. McDermott, and Vitoon Harusadangkul, "The Role, Status, and Working Conditions of Paraprofessionals: A National Survey of Academic Libraries," College \& Research Libraries 53 (May 1992): 224-231.

14. Ibid., 221.

15. Patricia A. Eskoz, "The Catalog Librarian-Change or Status Quo? Results of a Survey of Academic Libraries," Library Resources \& Technical Services 34 (July 1990): 380.

16. Ibid., 391.

17. Jane B. Robbins, "Fiction and Reality in Educating Catalogers," in Sheila S. Intner and Janet Swan Hill, eds., Cataloging: The Professional Development Cycle (New York: Greenwood Pr., 1991), 60 .

18. Clark, "Managing Copy Cataloging in ARL Libraries," 2.

19. Judith Hudson, "On-the-Job Training for Cataloging and Classification," Cataloging \& Classification Quarterly 7, no. 4 (1987): 72.

20. Younger, "Support Staff and Librarians in Cataloging," 33.

21. Hiatt, "Education and Training of Cataloging Staff at the Library of Congress," 126.

22. Clark, "Managing Copy Cataloging in ARL Libraries," 2.

23. Robbins, "Fiction and Reality in Educating Catalogers," 66.

24. Johnson, "The Changing Nature of Jobs," 60.

25. Chervinko, "The Changing State of Original Cataloging," 494.

26. Intner, "The Education of Copy Catalogers," 4. 